\title{
Allozymes and RAPDs detect little genetic population substructuring in the Caribbean stoplight parrotfish Sparisoma viride
}

\author{
Gerard J. Geertjes ${ }^{1,2}$, Jeroen Postema ${ }^{1}$, Albert Kamping ${ }^{2}$, Wilke van Delden ${ }^{2}$, \\ John J. Videler ${ }^{1, *}$, Louis van de Zande ${ }^{2}$ \\ ${ }^{1}$ Department of Marine Biology, and ${ }^{2}$ Department of Evolutionary Genetics, University of Groningen, \\ Centre for Ecological and Evolutionary Studies, PO Box 14, 9750 AA Haren, The Netherlands
}

\begin{abstract}
The genetic population structure of the Caribbean stoplight parrotfish Sparisoma viride was analysed by means of allozyme electrophoresis and randomly amplified polymorphic DNA (RAPD) using blood samples from adult fish that were collected on the reefs of 5 islands ( 3 sites at Bonaire, 1 each at Curaçao, Jamaica, Tobago and Saba). All allozyme loci showed a single very common allele. Allele frequency differences among the locations were mainly found for rare alleles. Genetic distances among the 7 sample sites ranged from less than 0.0001 to 0.012 . The fixation index $\left(F_{\mathrm{ST}}\right)$ for the allozyme loci was 0.0188 . Pairwise single enzyme locus $F_{\mathrm{ST}}$ values were small, but some $F_{\mathrm{ST}}$ values differed significantly from zero. The allozyme analysis detected significant $F_{\mathrm{ST}}$ values between Curaçao and the other sample sites. The RAPD data indicated high, but slightly restricted, gene flow among 5 geographic areas. Apparently, dispersal among islands is sufficient to maintain near-homogeneous allele frequencies. We conclude that the local $S$. viride sub-populations are relatively open and there is a high level of migration among them.
\end{abstract}

KEY WORDS: Reef fish $\cdot$ Population genetics $\cdot$ Gene flow $\cdot$ Allozymes $\cdot$ RAPD $\cdot$ Dispersal $\cdot$ Sparisoma viride

Resale or republication not permitted without written consent of the publisher

\section{INTRODUCTION}

The life-history of most coral reef fishes consists of 2 distinct phases: relatively sedentary demersal adults produce potentially dispersive pelagic eggs and larvae (Sale 1980). The fate of the pelagic stages of coral reef organisms is a matter of dispute. They may be dispersed among reefs by large-scale currents and finally settle onto reefs hundreds of kilometres away that could have environmental characteristics different to the reefs from where they originated (Barlow 1981) or contrastingly, they could be retained in local hydrographic features and subsequently recruit into the natal population (Johannes 1978). When larvae are locally retained, the reproductive output of a population can potentially impact local recruitment, whereas dispersal of larvae may disrupt any relationship be- tween reproduction and recruitment of a local population (e.g. Warner \& Cowen 2002). Insight into the pelagic phase of reef organisms may be of critical importance to coral reef conservation and fisheries management (Stobutzki 2001).

In populations of marine organisms, there are generally no pronounced barriers that prevent gamete broadcasting, recruitment of individuals from distant areas or adult migration (Ward et al. 1994). Although coral reef fishes inhabit highly fragmented habitats, many species have genetically homogeneous populations that inhabit large geographic ranges (e.g. Shaklee 1984, Lacson 1992, Planes et al. 1993). However, a number of studies have shown that even in the sea, gene flow can be sufficiently restricted to allow genetic population substructuring: in sessile organisms such as marine plants (e.g. Wright et al. 2000, Engelen et al. 
2001), marine invertebrates (Boisselier-Dubayle \& Gofas 1999, Huang et al. 2000, Luttikhuizen et al. 2003, Star et al. 2003), but also in vagile species such as temperate fishes (e.g. Mamuris et al. 1998a,b) and coral reef fishes (e.g. Doherty et al. 1995, Planes et al. 1996, 1998). Populations of many reef fishes resemble the 'patchy population' model that Harrison (1991) proposed for subdivided populations that are stable through time and where gene flow is sufficient to prevent differential allele fixation in local populations, but small enough for local differentiation in frequencies of neutral alleles. For management purposes, it may prove useful to apply the metapopulation concept to coral reef fishes (Grimm et al. 2003).

The stoplight parrotfish Sparisoma viride (Bonnaterre, 1788) is a large herbivore, common on Caribbean coral reefs (Böhlke \& Chaplin 1993, Bernardi et al. 2000), where it plays an important role in the trophodynamics of the coral reef ecosystem (Bruggemann et al. 1996, van Rooij et al. 1998). S. viride is a protogynous hermaphrodite (Reinboth 1968) with 2 distinct adult colour phases. Most initial phase $S$. viride are female, they have a mottled brown and red body colour. All terminal phase individuals are males that have a green body colour and distinct yellow spots on the caudal fin and gill covers. Adult $S$. viride seldom stray far from the coral reef (Böhlke \& Chaplin 1993, G. J. Geertjes pers. obs.). S. viride reproduction has been the subject of many studies (Munro et al. 1973, Robertson \& Warner 1978, Cardwell \& Liley 1991, Koltes 1993, van Rooij et al. 1996). The species shows a broad repertoire of reproductive strategies and reproductive systems differ among locations. Individual fish are possibly able to adjust their reproductive strategies to the conditions into which they happened to recruit. The potential for such phenotypic plasticity would be highly adaptive when chances are high for progeny not to recruit into the parental population, i.e. in the case of random recruitment. In such cases, the levels of gene flow among (sub)-populations at different reefs will be high and there will be little genetic divergence. Contrastingly, genetic adaptation of reproductive strategies to local conditions may have developed when many generations recruited into the natal population, i.e. when larval dispersal and gene flow among sites with different circumstances is highly restricted. In that case, genetic divergence among sub-populations at different sites is expected.

Until recently, Sparisoma viride was thought to occur on coral reefs throughout the tropical Western Atlantic (Böhlke \& Chaplin 1993); however, a study by De Moura et al. (2001) showed that the populations inhabiting the reefs of Brazil actually constitute a distinct endemic species: Sparisoma amplum. For the stoplight parrotfish, the freshwater plumes of the Orinoco and Amazon rivers apparently form an effective barrier to migration between the Caribbean and the southwestern Atlantic.

The main objective of this study was to determine the genetic population structure of Sparisoma viride and by inference gain insight into the dispersal of the early life-history stages and the phenotypic adaptation of this species.

\section{MATERIALS AND METHODS}

Sampling. We collected 319 stoplight parrotfish Sparisoma viride at the islands Bonaire (3 sites on the leeward coast: Slagbaai, Karpata and Salt City), Curaçao, Jamaica, Tobago and Saba (Fig. 1, Table 1). Most of the fish were captured alive at night using hand-nets and Scuba gear, but 36 live or freshly killed fish were put at

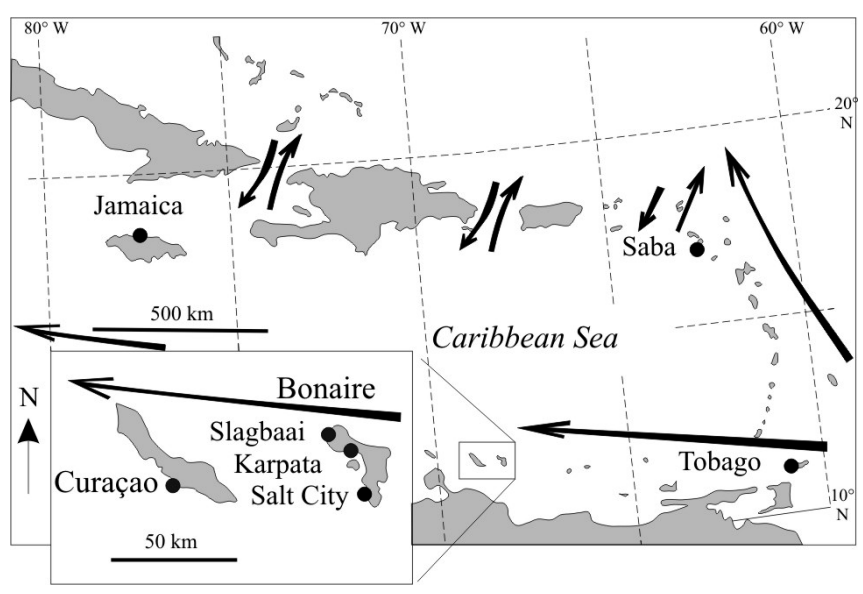

Fig. 1. Sparisoma viride. Map of the SE Caribbean showing sampling sites of $S$. viride indicated by $\bullet$. Arrows indicate the direction of the predominant surface ocean currents

Table 1. Sparisoma viride. Samples collected for allozyme and RAPD analysis, number of intial phase (Ip) and terminal phase (Tp) fish sampled and capture method used

\begin{tabular}{|c|c|c|c|c|c|c|}
\hline \multirow{2}{*}{ Sample site } & \multicolumn{3}{|c|}{ Allozyme } & \multicolumn{3}{|c|}{$\longrightarrow$ RAPD } \\
\hline & Handnet & Fishermen & Total & Handnet & Fishermen & Total \\
\hline Karpata (Bonaire) & $32 \mathrm{Ip}, 13 \mathrm{Tp}$ & - & 45 & $16 \mathrm{Ip}, 4 \mathrm{Tp}$ & - & 20 \\
\hline Salt City (Bonaire) & $26 \mathrm{Ip}, 18 \mathrm{Tp}$ & - & 44 & $14 \mathrm{Ip}, 6 \mathrm{Tp}$ & - & 20 \\
\hline Slagbaai (Bonaire) & $25 \mathrm{Ip}, 27 \mathrm{Tp}$ & - & 52 & $13 \mathrm{Ip}, 7 \mathrm{Tp}$ & - & 20 \\
\hline Curaçao & $25 \mathrm{Ip}, 34 \mathrm{Tp}$ & - & 59 & $3 \mathrm{Ip}, 17 \mathrm{Tp}$ & - & 20 \\
\hline Jamaica & $8 \mathrm{Ip}, 8 \mathrm{Tp}$ & $7 \mathrm{Ip}, 7 \mathrm{Tp}$ & 30 & $8 \mathrm{Ip}, 4 \mathrm{Tp}$ & $4 \mathrm{Ip}, 4 \mathrm{Tp}$ & 20 \\
\hline Tobago & $20 \mathrm{Ip}, 8 \mathrm{Tp}$ & - & 28 & $14 \mathrm{Ip}, 6 \mathrm{Tp}$ & - & 20 \\
\hline Saba & - & $2 \mathrm{Ip}, 6 \mathrm{Tp}$ & 8 & - & $5 \mathrm{Ip}, 13 \mathrm{Tp}$ & 18 \\
\hline
\end{tabular}


our disposal by local fishermen and returned to them after sampling. Hand-caught fish were anaesthetised in a $100 \mathrm{mg} \mathrm{l}^{-1}$ solution of the fish anaesthetic MS222 in aerated seawater. Fish intended for human consumption were stunned by a sharp blow to the head if necessary. Blood samples of approximately $1.5 \mathrm{ml}$ were drawn from the caudal vein. To prevent re-capture of the same individuals, sampled fish were marked by clipping the upper lobe of the caudal fin. The fish were placed in large containers with continually aerated seawater to recover for at least $60 \mathrm{~min}$ and then released at the location from where they were caught.

Sample preservation. Approximately $1 \mathrm{ml}$ of blood intended for enzyme electrophoresis was added to a pre-sterilised cryotube containing $0.3 \mathrm{ml}$ of ACG buffer $(0.48 \%$ citric acid; $1.32 \%$ sodium citrate; $1.47 \%$ glucose [\%weight] adapted after White \& Densmore 1992) frozen at $-20^{\circ} \mathrm{C}$ and stored at $-80^{\circ} \mathrm{C}$. Blood intended for DNA extraction was preserved after Aggarwal et al. (1992). Of each blood sample, 0.4 to $0.5 \mathrm{ml}$ was smeared on a sterilised microscope slide. The blood smears were air-dried at ambient temperature, which took about 1 to $4 \mathrm{~h}$. Each dried sample was covered with a second glass slide, wrapped in aluminium foil and stored in a desiccator with silica gel to prevent hydration. All fin lobes that were removed for tagging were stored in $2.5 \mathrm{ml} 96 \%$ ethanol and served as back-up tissue for DNA extraction in case a blood sample was spoiled or not available.

Enzyme electrophoresis. Prior to electrophoresis, appropriate amounts of blood were thawed over ice and homogenised in a buffer solution $(0.01 \mathrm{M}$ Triscitrate $\mathrm{pH} 7.0 ; 0.3 \mathrm{mg} \mathrm{ml}^{-1} \mathrm{NAD}^{ \pm}$; ratio $\pm 1 \mathrm{ml}$ buffer $\mathrm{g}^{-1}$ blood) using precooled pestles and mortars (diameter $5 \mathrm{~cm}$ ) and $\pm 2 \mathrm{mg}$ of sand. Homogenates were subjected to horizontal starch-gel $(12 \% \mathrm{w} / \mathrm{v})$ electrophoresis as described by Geertjes et al. (2001). After electrophoresis, gels were stained using recipes of Hofman (1988) and Murphy et al. (1996), with slight modifications. The samples were screened for 13 enzymes on the following buffer systems: continuous Tris-citrate $\mathrm{pH} 7.0$ (Hofman 1988), continuous Tris-citrate EDTA pH 7.5 (Murphy et al. 1996), discontinuous LiOH-borate pH 8.3 (Hofman 1988) and continuous Tris-borate-EDTA pH 8.6 (van Dijk \& van Delden 1981, van Treuren et al. 1991) (Table 2). Patterns of allozyme variation, consistent with the subunit structure of each enzyme and with simple models of Mendelian inheri- tance, were recorded as genotypes. Locus designation follows nomenclature for fish genes as proposed by Shaklee et al. (1990). Alleles at the same locus were designated as their migration distance relative to the migration distance of the most common allele, which was stated at 100 .

DNA extraction. Before DNA extraction, each bloodsmeared slide was cut in half. One half was rewrapped and retained as a back-up. The other half was placed in a cuvette containing $5 \mathrm{ml}$ of TES/SDS lysis buffer (30 mM Tris-HCl, $5 \mathrm{mM}$ EDTA, $50 \mathrm{mM} \mathrm{NaCl}, \mathrm{pH}$ 8.0, $0.5 \%$ SDS). After the blood had soaked for $3 \mathrm{~min}$, the blood-lysis buffer mixture was pipetted into a sterile centrifuge tube and $50 \mu \mathrm{l}$ of Proteinase $\mathrm{K}\left(10 \mathrm{mg} \mathrm{ml}^{-1}\right)$ were added. The sample was well mixed by repeated inverting and incubated overnight at $55^{\circ} \mathrm{C}$. DNA was purified using standard phenol extraction followed by ethanol precipitation. DNA was spooled on a thin glass rod and washed twice in cold $70 \%$ ethanol, air-dried and dissolved in $1 \mathrm{ml} 0.1 \times$ TE buffer $\left(1 \mathrm{mM}\right.$ Tris- $\mathrm{HCl}_{\text {, }}$ $0.1 \mathrm{mM}$ EDTA, pH 7.5). DNA was extracted from the ethanol-preserved fin clip of a few fish for which no blood sample was available. The clip was dried with filter paper and scraped clean with a sterile scalpel. The remaining tissue was placed in a centrifuge tube with $5 \mathrm{ml}$ TES/SDS buffer, $50 \mu \mathrm{l}$ of Proteinase K $(10 \mathrm{mg}$ $\mathrm{ml}^{-1}$ ) were added and DNA extraction followed the same protocol as extraction from blood.

RAPD-PCR, DNA gel electrophoresis and visualisation. Ten arbitrary decamer primers (Operon Technologies) were used in RAPD-PCR amplification (Table 3), essentially as described by Williams et al. (1990). PCR

Table 2. Sparisoma viride. List of enzymes examined, Enzyme Commission numbers (EC no.), subunit structure (ss), putative loci and buffer system yielding best resolution (TC: tris-citrate $\mathrm{pH}$ 7.0; TCE: tris-citrate-EDTA pH 7.5; LB: LiOHborate/tris-citrate $\mathrm{pH}$ 8.3; TBE: tris-borate-EDTH pH 8.6)

\begin{tabular}{|llllc|}
\hline Enzyme & EC no. & ss & Locus & Buffer \\
\hline Acid phosphatase & 3.1 .3 .2 & 1 & $A C P-1^{*}$ & TC \\
Esterase & $3.1 .1 .-$ & 2 & $E S T^{*}$ & TC \\
Fumarate hydratase & 4.2 .1 .2 & 4 & $F H^{*}$ & TCE \\
Glucose-6-phosphate dehydrogenase & 1.1 .1 .49 & 2 & $G P D H^{*}$ & LB \\
Glucose-6-phosphate isomerase & 5.3 .1 .9 & 2 & $G P I^{*}$ & LB \\
Glyceraldehyde-3-phosphate dehydrogenase & 1.2 .1 .12 & 4 & $G A P D H^{*}$ & TBE \\
Isocitrate dehydrogenase & 1.1 .1 .42 & 2 & $I D H P^{*}$ & TC \\
Lactate dehydrogenase & 1.1 .1 .27 & 4 & $L D H-1^{*}$ & TCE \\
Malate dehydrogenase & 1.1 .1 .37 & 2 & $M D H^{*}$ & TCB \\
Malic enzyme (NADP+) & 1.1 .1 .40 & 4 & $M E P-1^{*}$ & LB \\
Phosphogluconate dehydrogenase & 1.1 .1 .44 & 2 & $P G D H^{*}$ & TC \\
Superoxide dismutase & 1.15 .1 .1 & 2 & $S S O D^{*}$ & TCE \\
Triose phosphate isomerase & 5.3 .1 .1 & 2 & $T P I-1^{*}$ & LB \\
\hline
\end{tabular}


Table 3. Sparisoma viride. RAPD primers used, primer sequence and number of bands found for each primer (number of polymorphic bands in parentheses)

\begin{tabular}{|lcc|}
\hline Primer & Primer sequence 5' to 3' & Number of bands \\
\hline OPF-03 & CCTGATCACC & $7(3)$ \\
OPF-05 & CCGAATTCCC & $14(12)$ \\
OPF-09 & CCAAGCTTCC & $12(7)$ \\
OPF-12 & ACGGTACCAG & $20(17)$ \\
OPF-15 & CCAGTACTCC & $11(8)$ \\
OPF-16 & GGAGTACTGG & $13(9)$ \\
OPF-18 & TTCCCGGGTT & $4(3)$ \\
OPF-20 & GGTCTAGAGG & $10(10)$ \\
OPG-06 & GTGCCTAACC & $16(15)$ \\
OPG-07 & GAACCTGCGG & $11(7)$ \\
Total & & $118(91)$ \\
\hline
\end{tabular}

reactions were carried out in $25 \mu \mathrm{l}$ reaction volume containing $2.5 \mu \mathrm{l} 10 \times$ SuperTaq reaction buffer $(\mathrm{H}$. T. Biotechnologies), $1.5 \mathrm{mM} \mathrm{MgCl}_{2}, 100 \mu \mathrm{M}$ dNTPs (Pharmacia LKB), 60 ng primer, 0.25 unit SuperTaq DNA polymerase (H. T. Biotechnologies) and $30 \mathrm{ng}$ genomic DNA. The reaction mix was overlaid with a drop of mineral oil to prevent evaporation and centrifuged briefly. Amplification was carried out in a Perkin Elmer Cetus DNA Thermal Cycler 480 programmed for $3 \mathrm{~min}$ at $94^{\circ} \mathrm{C}$ followed by 43 cycles each consisting of $1 \mathrm{~min}$ denaturation at $94^{\circ} \mathrm{C}, 1 \mathrm{~min}$ annealing at $36^{\circ} \mathrm{C}$ and 2 min elongation at $72^{\circ} \mathrm{C}$. Blank reaction mixes without template DNA were run with all RAPD amplifications. To check the reproducibility of the reactions, duplicate reactions were performed. PCR products were resolved by electrophoresis in $1.5 \%$ TAE buffered agarose gels for $4 \mathrm{~h}$ at $3 \mathrm{~V} \mathrm{~cm}^{-1}$ and stained with ethidiumbromide following standard methods (Sambrook et al. 1989). RAPD patterns were visualised by UV-fluorescence and photographed on Polaroid 665 positive/ negative Instant Pack film.

Data analysis. Enzyme allele frequencies, percentage of polymorphic loci (99\% criterion), mean number of alleles per locus, and mean observed and expected heterozygosity per locus per individual $\left(H_{\mathrm{o}}\right.$ and $H_{\mathrm{e}}$ respectively) were calculated. Genotype frequencies were tested for agreement with Hardy-Weinberg expectations using chi-squared statistics. In addition, $F_{\text {is }}$ values were calculated.

Nei's unbiased genetic distance (Nei 1978) was calculated between pairs of sample sites. The significance levels of the calculated $D$ values were tested by 10000 permutations of individuals between locations.

We quantified the effects of genetic population subdivision of Sparisoma viride using the fixation index $F_{\mathrm{ST}}$ (Wright 1951), estimated by $\theta$ of Weir \& Cockerham (1984). Single locus $F_{\text {ST }}$ values were calculated over the entire population, in 4 different groupings: all 7 sites separately, the 3 Bonairean sites pooled, Bonaire and $\mathrm{Cu}$ - raçao pooled, and all Southern sites pooled. Multi-locus $F_{\text {ST }}$ values were computed between locations. The probabilities of random departure from zero of the calculated $F_{\mathrm{ST}}$ values, both single- and multi-locus, were read from the distribution of 10000 randomised matrices computed by permutation of individuals between locations.

The level of gene flow among populations was estimated as the absolute number of migrants exchanged per generation at equilibrium $\left(N_{\mathrm{e}} \mathrm{m}\right)$, using an island model at low levels of migration, where $N_{\mathrm{e}} \mathrm{m}=\left(1-F_{\mathrm{ST}}\right)$ / $4 F_{\mathrm{ST}}$ (Wright 1951).

To test for possible sex-determined allelic differentiation, a preliminarily analysis of all initial phase versus all terminal phase individuals was carried out. No genetic differentiation was found among the life-history phases; therefore, the life-history phases were pooled per sample site for the population genetic analysis.

The level of RAPD polymorphism $(P)$ was calculated per location as the percentage of the total number of loci that were polymorphic. The level of genetic population subdivision was estimated using $\Phi$ statistics, which are directly analogous to Wright's F statistics (Excoffier et al. 1992). Analysis of molecular variance (AMOVA) (Excoffier et al. 1992) was used to estimate variance components for the RAPD phenotypes. Assumptions of population structure were tested and compared. Values of $\Phi_{\mathrm{ST}}$ between locations were calculated and their significance level tested by 5000 permutations of individuals between locations.

All tables of probabilities were adjusted for the number of simultaneous tests using a sequential Bonferroni correction (Rice 1989) to reduce the chance of type I errors.

Data analysis of allozymes was carried out using the computer packages GENETIX version 4.01 (Belkhir et al. 1997) and FSTAT 2.9.3.2 (Goudet, 1994). To analyse the RAPD data, we used the program ARLEQUIN, version 1.1 (Schneider et al. 1997). To determine possible correlations among geographic distance and genetic differentiation, Mantel tests (Mantel 1967) were performed on matrices of allozyme- $F_{\mathrm{ST}}$ and RAPD- $\Phi_{\mathrm{ST}}$ values and geographic distances using the computer package GENETIX version 4.01 (Belkhir et al. 1997).

\section{RESULTS}

\section{Allozyme electrophoresis}

Of the 17 enzyme loci tested, 16 appeared to be polymorphic (Table 4); only the locus TPI-1* was fixed for the same allele in all populations.

The mean number of alleles per locus in the 7 samples ranged from 1.4 for the smallest sample (Saba, mean $\mathrm{n}=6.8$ ) to 2.4 for the largest sample (Curaçao, 
Table 4. Sparisoma viride. Allele frequencies for 17 enzyme loci at 7 sampling locations (in parentheses: no. of specimens per locus)

\begin{tabular}{|c|c|c|c|c|c|c|c|c|c|c|c|c|c|c|c|}
\hline Locus & $\begin{array}{l}\text { Kar- } \\
\text { pata }\end{array}$ & $\begin{array}{l}\text { Salt } \\
\text { City }\end{array}$ & $\begin{array}{l}\text { Slag- } \\
\text { baai }\end{array}$ & $\begin{array}{c}\text { Cura- } \\
\text { çao }\end{array}$ & $\begin{array}{c}\text { Jam- } \\
\text { aica }\end{array}$ & $\begin{array}{c}\text { To- } \\
\text { bago }\end{array}$ & Saba & Locus & $\begin{array}{l}\text { Kar- } \\
\text { pata }\end{array}$ & $\begin{array}{l}\text { Salt } \\
\text { City }\end{array}$ & $\begin{array}{l}\text { Slag- } \\
\text { baai }\end{array}$ & $\begin{array}{c}\text { Cura- } \\
\text { çao }\end{array}$ & $\begin{array}{c}\text { Jam- } \\
\text { aica }\end{array}$ & $\begin{array}{c}\text { To- } \\
\text { bago }\end{array}$ & Saba \\
\hline$A C P-1^{*}$ & (45) & $(44)$ & (52) & (58) & (30) & (28) & (8) & $I D H P^{*}$ & (45) & (44) & (52) & (59) & (30) & (28) & (8) \\
\hline 84 & - & - & - & - & 0.033 & - & - & 69 & - & 0.011 & - & - & - & - & - \\
\hline 92 & 0.044 & 0.023 & 0.038 & 0.069 & 0.050 & 0.054 & - & 100 & 0.989 & 0.989 & 1.000 & 0.991 & 1.000 & 1.000 & 1.000 \\
\hline 100 & 0.867 & 0.886 & 0.885 & 0.871 & 0.883 & 0.821 & 0.938 & 125 & 0.011 & - & - & - & - & - & - \\
\hline 104 & - & - & 0.010 & 0.009 & - & - & - & 144 & - & - & - & 0.009 & - & - & - \\
\hline 112 & 0.089 & 0.091 & 0.067 & 0.052 & 0.033 & 0.125 & 0.063 & $L D H-1^{*}$ & (29) & $(27)$ & (38) & (58) & (23) & (11) & (4) \\
\hline$A C P-2^{*}$ & (43) & (42) & (50) & (58) & (28) & (27) & (8) & 67 & - & - & - & - & 0.022 & - & - \\
\hline 80 & - & - & - & - & - & - & 0.063 & 100 & 0.931 & 0.963 & 0.908 & 0.991 & 0.978 & 0.909 & 1.000 \\
\hline 85 & 0.012 & - & - & - & - & - & - & 167 & 0.069 & 0.037 & 0.092 & 0.009 & - & 0.091 & - \\
\hline 93 & 0.151 & 0.131 & 0.100 & 0.216 & 0.071 & 0.093 & - & & & & & & & & \\
\hline 100 & 0.837 & 0.845 & 0.900 & 0.776 & 0.911 & 0.907 & 0.875 & $L D H-2^{*}$ & $(45)$ & $(44)$ & (52) & (59) & (30) & $(28)$ & (8) \\
\hline 103 & - & 0.024 & - & 0.009 & 0.018 & - & 0.063 & 74 & 0.044 & 0.057 & 0.067 & 0.017 & 0.117 & 0.125 & 0.313 \\
\hline & & & & & & & 0.003 & 84 & 0.089 & 0.148 & 0.135 & 0.051 & 0.117 & 0.232 & 0.188 \\
\hline$E S T^{*}$ & (45) & (44) & (52) & (59) & (30) & (28) & (8) & 100 & 0.844 & 0.773 & 0.779 & 0.932 & 0.767 & 0.643 & 0.500 \\
\hline 88 & - & - & - & 0.025 & - & - & - & 111 & 0.022 & 0.023 & 0.019 & - & - & - & - \\
\hline 93 & 0.022 & - & - & - & - & - & - & & & & & & & & \\
\hline 98 & 0.011 & 0.011 & 0.029 & 0.025 & - & - & - & $M D H^{*}$ & $(41)$ & (39) & $(45)$ & (59) & $(30)$ & $(24)$ & (6) \\
\hline 100 & 0.967 & 0.989 & 0.971 & 0.949 & 1.000 & 1.000 & 1.000 & 100 & 0.951 & 0.936 & 0.944 & 1.000 & 0.933 & 0.896 & 0.750 \\
\hline & & & & & & & & 144 & 0.049 & 0.064 & 0.056 & - & 0.050 & 0.104 & 0.250 \\
\hline$F H^{*}$ & (39) & (36) & (42) & (59) & (26) & (17) & (5) & 222 & - & - & - & - & 0.017 & - & - \\
\hline 60 & - & - & - & 0.008 & - & - & - & & & & & & & & \\
\hline 80 & - & 0.014 & 0.012 & 0.017 & - & - & - & $M E P-1^{*}$ & (43) & (43) & (51) & (57) & (19) & (26) & (8) \\
\hline 100 & 1.000 & 0.972 & 0.988 & 0.975 & 1.000 & 1.000 & 1.000 & 79 & 0.081 & 0.012 & 0.029 & 0.026 & 0.053 & 0.038 & - \\
\hline 132 & - & 0.014 & - & - & - & - & - & 95 & - & - & - & 0.009 & 0.026 & - & - \\
\hline$G 6 P D H^{*}$ & (45) & (44) & & & & & & 100 & 0.919 & 0.988 & 0.971 & 0.965 & 0.921 & 0.962 & 1.000 \\
\hline 100 & $\begin{array}{c}(45) \\
0800\end{array}$ & $\begin{array}{c}(44) \\
0.920\end{array}$ & $\begin{array}{c}(51) \\
0843\end{array}$ & (59) & $(27)$ & (25) & (6) & $M F P-2^{*}$ & (38) & $(40)$ & $(49)$ & (59) & (20) & (28) & (8) \\
\hline 108 & 0.200 & 0.080 & $\begin{array}{l}0.843 \\
0.157\end{array}$ & 0.932 & $\begin{array}{l}0.833 \\
0.167\end{array}$ & $\begin{array}{l}0.840 \\
0160\end{array}$ & $\begin{array}{c}1.000 \\
-\end{array}$ & $\begin{array}{c}\text { NILF-2 } \\
90\end{array}$ & - & - & - & 0.017 & - & - & - \\
\hline & & 0.000 & & & & & & 100 & 0.987 & 0.975 & 0.969 & 0.983 & 1.000 & 0.839 & 1.000 \\
\hline$G A P D H^{*}$ & $*(45)$ & (44) & (52) & (59) & (30) & (28) & (5) & 124 & 0.013 & 0.025 & 0.031 & - & - & 0.161 & - \\
\hline 80 & - & - & - & 0.017 & 0.017 & - & - & & & & & & & & \\
\hline 93 & - & - & - & - & - & 0.018 & - & $P G D H^{*}$ & (45) & (40) & $(47)$ & (59) & (24) & (17) & (5) \\
\hline 100 & 0.989 & 1.000 & 1.000 & 0.983 & 0.983 & 0.982 & 1.000 & 93 & - & - & 0.011 & 0.008 & - & 0.029 & - \\
\hline 120 & 0.011 & - & - & - & - & - & - & 100 & 1.000 & 1.000 & 0.989 & 0.992 & 1.000 & 0.971 & 1.000 \\
\hline$G P I^{*}$ & $(42)$ & (41) & $(47)$ & (59) & (26) & $(18$ & (5) & ${ }_{S S O D}^{*}$ & (45) & $(44)$ & (52) & (59) & (30) & (28) & (8) \\
\hline 40 & - & - & - & - & - & 0.028 & (J) & 100 & 1.000 & 0.989 & 1.000 & 1.000 & 1.000 & 1.000 & 1.000 \\
\hline 80 & - & - & - & 0.008 & - & - & - & 215 & - & 0.011 & - & - & - & - & - \\
\hline 84 & - & 0.012 & - & 0.008 & - & - & - & TPI-1* & $(45)$ & (41) & $(50)$ & (59) & $(30)$ & (28) & (8) \\
\hline 88 & - & - & 0.011 & - & - & - & - & $\begin{array}{c}T P I-1^{*} \\
100\end{array}$ & $\begin{array}{c}(45) \\
1.000\end{array}$ & $\begin{array}{c}(41) \\
1.000\end{array}$ & $\begin{array}{c}(50) \\
1.000\end{array}$ & $\begin{array}{c}\text { (59) } \\
1.000\end{array}$ & $\begin{array}{l}(30) \\
1.000\end{array}$ & $\begin{array}{l}(20) \\
1.000\end{array}$ & 1.000 \\
\hline 92 & 0.012 & - & 0.011 & - & 0.038 & - & 0.100 & & & & & & & & \\
\hline 100 & 0.988 & 0.976 & 0.947 & 0.949 & 0.923 & 0.972 & 0.900 & TPI-2* & (45) & (44) & 52) & & (30) & (28) & (7) \\
\hline 112 & - & - & 0.011 & 0.025 & 0.038 & - & - & 94 & - & - & - & 0.009 & - & - & - \\
\hline 116 & - & 0.012 & 0.021 & 0.008 & - & - & - & 100 & 1.000 & 1.000 & 1.000 & 0.991 & 1.000 & 1.000 & 1.000 \\
\hline
\end{tabular}

mean $\mathrm{n}=58.7$ ) and was 3.5 over all samples (mean $\mathrm{n}=250.3)$. The percentage of enzyme loci that were polymorphic under the 0.99 criterion ranged from $29.4 \%$ (Saba) to $76.5 \%$ (Salt City) and was $64.7 \%$ overall. The values for $H_{0}$ ranged from 0.087 (SE 0.025, Curaçao) to 0.118 (SE 0.036, Tobago) and was 0.091 (SE 0.026) over all samples, while the values for $H_{\mathrm{e}}$ ranged from 0.076 (SE 0.023, Curaçao) to 0.126 (SE 0.037, Tobago) and was 0.094 (SE 0.025) overall (Table 5). No significant deviations from Hardy-Weinberg proportions were observed in any of the samples after applying the sequential Bonferroni correction (significance level $\alpha=0.05$ ). This is confirmed by the fact that $F_{\text {is }}$ values, which measure the reduction in heterozygosity of an individual due to non-random mating within its sub-population, did not significantly differ from zero (Table 6) for any of the sampling sites, and yielded a multi-locus value of $F_{\text {is }}=0.001$ (95\% CI -0.083 to 0.109$)$. It should be noted, however, that $F_{\text {is }}$ values for the population of Slagbaai are at the verge of significance.

Nei's genetic distances among the 7 sample sites ranged from $>0.0001$ to 0.012 (Table 7 ). Several pairwise genetic distances appeared to differ significantly from zero (see Table 7) when tested using the permutations method of the GENETIX computer package (Belkhir et al. 1997) and after applying the sequential Bonferroni correction for multiple tests (Rice 1989). 
Table 5. Sparisoma viride. Gene variability for 7 sampling sites, $n$ : sample size per enzyme locus (mean and SE); $A$ : number of alleles per enzyme locus (mean and SE); $P_{99}$ : percentage allozyme loci polymorphic at the $99 \%$ criterion; $H_{0}$ : observed allozyme heterozygosity (mean and SE); $H_{\mathrm{e}}$ the expected allozyme heterozygosity (mean and SE); $P_{0 \text {-RAPD }}$ percentage of polymorphic RAPD loci at the $100 \%$ criterion

\begin{tabular}{|lrccccc|}
\hline Sample & $n$ & $A$ & $P_{99}$ & $H_{\mathrm{o}}$ & $H_{\mathrm{e}}$ & $P_{0-\mathrm{RAPD}}$ \\
\hline Karpata & $42.6(1.0)$ & $2.0(0.2)$ & 70.6 & $0.102(0.029)$ & $0.098(0.028)$ & 43.2 \\
Salt City & $41.2(1.1)$ & $2.1(0.2)$ & 76.5 & $0.089(0.031)$ & $0.085(0.027)$ & 40.7 \\
Slagbaai & $49.1(1.0)$ & $2.1(0.3)$ & 70.6 & $0.087(0.025)$ & $0.096(0.027)$ & 41.5 \\
Curaçao & $58.7(0.1)$ & $2.4(0.3)$ & 58.8 & $0.077(0.027)$ & $0.076(0.023)$ & 33.9 \\
Jamaica & $27.4(0.8)$ & $1.9(0.2)$ & 52.9 & $0.093(0.031)$ & $0.092(0.029)$ & 41.5 \\
Tobago & $24.5(1.3)$ & $1.8(0.2)$ & 64.7 & $0.118(0.036)$ & $0.126(0.037)$ & 36.4 \\
Saba & $6.8(0.4)$ & $1.4(0.2)$ & 29.4 & $0.093(0.042)$ & $0.096(0.045)$ & 33.9 \\
All & $250.3(4.9)$ & $3.5(0.4)$ & 64.7 & $0.091(0.026)$ & $0.094(0.025)$ & 77.1 \\
\hline
\end{tabular}

\section{RAPDs}

RAPD analysis resolved 118 bands of which 91 were polymorphic at the $99 \%$ criterion. The number of bands per primer varied from 4 to 20 (Table 3). Each individual fish showed a unique RAPD phenotype.

Twenty-three location-specific bands were found, all but 2 of them were singly occurring rare alleles. The level of polymorphism in the 7 samples was similar (Table 5), ranging from 33.9\% (Saba and Curaçao) to $43.2 \%$ (Karpata).

The fixation index $\Phi_{\mathrm{ST}}$ for all 7 samples was 0.0438 and highly significant

The multi-locus fixation index over the entire population was $F_{\mathrm{ST}}=0.0188$ and significantly different from zero (95\% CI 0.004 to 0.032), indicating a low level of genetic differentiation among sub-populations at the 5 islands. The overall number of effective migrants $\left(N_{\mathrm{e}} \mathrm{m}\right)$ was 13.05 ind. per generation. Significant values for multi-locus pairwise $F_{\mathrm{ST}}$ distinguish Curaçao from each of the other islands (Table 7).

The Bonairean samples were pooled for the allozyme data analysis as the values for pairwise single locus $F_{\mathrm{ST}}$ did not show a single significant difference between any of the sites at Bonaire for any locus (Table 7). Pairwise single locus $F_{\mathrm{ST}}$ values showed significant differentiation between sample sites for several loci (Table 7). Curaçao is distinguished from all the other islands by significant $F_{\mathrm{ST}}$ values for the locus $L D H-2^{*}$ and either of the loci $M D H^{*}$ or TPI-2* . Tobago is distinguished from Bonaire, Curaçao and Jamaica by significant $F_{\mathrm{ST}}$ values for the locus MEP-2* . No significant correlation was found between values of pairwise $F_{\mathrm{ST}}$ and geographic distance (Mantel test, $Z=1048.05$, $r=0.158 ; \mathrm{p}=0.344)$.

Table 6. Sparisoma viride. $F_{\text {is }}$ values for the 7 sampling sites, $n$ : sample size per enzyme locus (mean and SE); Proplarger: proportion of randomisations that gave a larger $F_{\text {is }}$ than the observed; Prop smaller: $_{\text {: }}$ proportion of randomisations that gave a smaller $F_{\text {is }}$ than the observed, based on 2380 randomisations. Indicative adjusted nominal level (5\%): 0.00042

\begin{tabular}{|lcrcc|}
\hline Sample & $n$ & \multicolumn{1}{c}{$F_{\text {is }}$} & Prop $_{\text {larger }}$ & Prop \\
\hline Karpata & $42.6(1.0)$ & -0.108 & 1.0000 & 0.0067 \\
Salt City & $41.2(1.1)$ & -0.042 & 0.8655 & 0.1752 \\
Slagbaai & $49.1(1.0)$ & 0.106 & 0.0092 & 0.9912 \\
Curaçao & $58.7(0.1)$ & -0.001 & 0.5479 & 0.4601 \\
Jamaica & $27.4(0.8)$ & -0.012 & 0.5345 & 0.4706 \\
Tobago & $24.5(1.3)$ & 0.071 & 0.1197 & 0.8832 \\
Saba & $6.8(0.4)$ & 0.037 & 0.4248 & 0.7256 \\
\hline
\end{tabular}

( $p<0.0001)$. AMOVA showed that a very small amount of variation is partitioned in the 'among samples or sample groups' category and more than $95 \%$ of the RAPD variation was partitioned within samples, or sample groups. The amount of variation among samples within groups increased when the samples were placed in different groups according to increasing geographic distance, except when Karpata was grouped with Salt City and Slagbaai (the Bonaire sampling site nearest to Curaçao) with Curaçao (Fig. 1, Table 8) When the individuals from Karpata were pooled with those from Salt City and the ones from Curaçao with those from Slagbaai, the values of pairwise $\Phi_{\mathrm{ST}}$ among all sub-populations differed significantly from zero, also after applying sequential Bonferroni correction (significance level $\alpha=0.05$ ), although the values of $\Phi_{\mathrm{ST}}$ were very low (Table 9). There was no significant relationship between values of pairwise $\Phi_{\mathrm{ST}}$ and geographic distance (Mantel test, $Z=1681.66, r=0.390$; $\mathrm{p}=0.193)$.

We found no correlation between the values of pairwise $F_{\mathrm{ST}}$ from the allozyme electrophoresis and of pairwise $\Phi_{\mathrm{ST}}$ from the RAPD analysis (Mantel test, $Z=0.05$, $r=-0.009, \mathrm{p}=0.860$ ).

\section{DISCUSSION}

The low fixation index values detected by both methods indicate little population genetic substructuring in the Caribbean stoplight parrotfish. Apparently the island (sub)-populations generally form a nearhomogeneous assemblage. Neither method produced markers that specifically discriminate populations. The level of gene diversity detected by allozyme electrophoresis was somewhat higher than that found by RAPDs; both methods produced patterns of slight genetic population substructuring. 
Table 7. Sparisoma viride. Allozyme analysis. Above the diagonal: values of multi-locus $F_{\mathrm{ST}}$ pairwise between samples (Weir \& Cockerham 1984), *: significant at Bonferroni adjusted $\mathrm{p} \leq 0.05$; the number of migrants per generation $\left(N_{\mathrm{e}} m_{1}\right)$ exchanged under the island model hypothesis: $N_{\mathrm{e}} \mathrm{m}=\left(1-F_{\mathrm{ST}}\right) / 4 F_{\mathrm{ST}}$ (Wright 1951), $\bullet:$ no $N_{\mathrm{e}} \mathrm{m}$ can be calculated due to a negative value of $F_{\mathrm{ST}}$ loci which show significant differentiation between the 2 compared samples (significance levels Bonferroni adjusted). Below the diagonal: values of Nei's unbiased genetic distance $D$ (Nei 1978)

\begin{tabular}{|c|c|c|c|c|c|c|c|c|c|c|}
\hline & & Karpata & Salt City & Slagbaai & Bonaire & Curaçao & Jamaica & Tobago & Saba & \\
\hline Karpata & & - & $\begin{array}{c}0.0065 \\
38\end{array}$ & $\begin{array}{c}-0.0025 \\
\bullet\end{array}$ & & $\begin{array}{l}0.0173 \\
14 \\
M D H\end{array}$ & $\begin{array}{c}0.0008 \\
301\end{array}$ & $\begin{array}{c}0.0215 \\
11 \\
M E P-2 P G D H\end{array}$ & $\begin{array}{c}0.0842 \\
3 \\
L D H-2\end{array}$ & $\begin{array}{l}F_{\mathrm{ST}} \\
N_{\mathrm{e}} \\
\text { loci }\end{array}$ \\
\hline Salt City & $D$ & 0.001 & - & $\begin{array}{c}-0.0028 \\
\bullet\end{array}$ & & $\begin{array}{c}0.0158 \\
16 \\
L D H-2 M D H\end{array}$ & $\begin{array}{l}0.0032 \\
79 \\
\text { GAPDH }\end{array}$ & $\begin{array}{c}0.0141 \\
18 \\
M E P-2 \text { GAPDH PGDH }\end{array}$ & $\begin{array}{c}0.0490 \\
5\end{array}$ & $\begin{array}{l}F_{\mathrm{ST}} \\
N_{\mathrm{e}} \\
\text { loci }\end{array}$ \\
\hline Slagbaai & $D$ & 0.000 & 0.000 & - & & $\begin{array}{c}0.0257^{*} \\
10 \\
L D H-1 L D H-2 M D H\end{array}$ & $\begin{array}{l}-0.0051 \\
\bullet \\
G A P D H\end{array}$ & $\begin{array}{c}0.0051 \\
49 \\
M E P-2 \text { GAPDH }\end{array}$ & $\begin{array}{c}0.0471 \\
5\end{array}$ & $\begin{array}{l}F_{\mathrm{ST}} \\
N_{\mathrm{e}} \\
\text { loci }\end{array}$ \\
\hline Bonaire & & & & & - & $\begin{array}{c}0.0183^{*} \\
13 \\
L D H-2 T P I-2\end{array}$ & -0.0009 & $\begin{array}{c}0.0016 \\
159 \\
L D H-2 M E P-2\end{array}$ & $\begin{array}{c}0.0605 \\
4 \\
L D H-2 M D H\end{array}$ & $\begin{array}{l}F_{\mathrm{ST}} \\
N_{\mathrm{e}} \\
\text { loci }\end{array}$ \\
\hline Curaçao & $D$ & 0.002 & $0.002^{*}$ & $0.002^{*}$ & 0.002 & - & $\begin{array}{c}0.0298^{*} \\
8 \\
L D H-2 M D H\end{array}$ & $\begin{array}{c}0.0698^{*} \\
3 \\
H D H-2 M D H M E P-2\end{array}$ & $\begin{array}{c}0.1345^{*} \\
2 \\
L D H-2 M D H\end{array}$ & $\begin{array}{l}F_{\mathrm{ST}} \\
N_{\mathrm{e}} \\
\text { loci }\end{array}$ \\
\hline Jamaica & $D$ & 0.000 & 0.001 & 0.000 & 0.000 & $0.003^{*}$ & - & $\begin{array}{c}0.0131 \\
19 \\
M E P-2 \text { PGDH }\end{array}$ & $\begin{array}{c}0.0413 \\
6\end{array}$ & $\begin{array}{l}F_{\mathrm{ST}} \\
N_{\mathrm{e}} \\
\text { loci }\end{array}$ \\
\hline Tobago & $D$ & 0.002 & 0.003 & 0.000 & 0.001 & $0.006^{*}$ & 0.001 & - & $\begin{array}{c}0.0144 \\
17\end{array}$ & $\begin{array}{l}F_{\mathrm{ST}} \\
N_{\mathrm{e}} \\
\text { loci }\end{array}$ \\
\hline Saba & $D$ & $0.008^{*}$ & 0.003 & 0.005 & $0.007^{*}$ & $0.012^{*}$ & 0.004 & 0.004 & - & \\
\hline
\end{tabular}

The level of allozyme polymorphism in Sparisoma viride is relatively high compared to published data on other fish species. The $H_{0}$, which ranges from 0.087 in Curaçao to 0.118 in Tobago, with an overall value of 0.091 (SE 0.026), is high compared to the average value of heterozygosity $(\bar{H})$ of $0.055 \pm 0.036$ (SD) reported by Smith \& Fujio (1982) for 89 marine teleosts and the $\bar{H}$ of $0.064 \pm 0.004$ (SE) found for 113 fish species by Ward et al. (1994). Although not statistically significant, this relatively high allozyme polymorphism may indicate that $S$. viride has a large effective population size, as levels of polymorphism in fish are more closely related to effective population size than to any known ecological factor (Rasmuson 1981) and marine fishes that have large populations have higher gene diversity levels than organisms with much smaller populations (Gyllensten 1985).

In Sparisoma viride, each allozyme locus shows a most common allele that is prevalent at all locations and 1 or more relatively rare alleles that are often restricted to a single island or are present at low frequencies in several island sub-populations.
The exchange among sub-populations of more than 1 reproductive migrant per generation is theoretically sufficient to ensure the presence of identical alleles, while higher migration rates maintain homogeneous allele frequencies (Allendorf \& Phelps 1981, Slatkin 1987). Genetic homogeneity in coral reef fish populations is usually attributed to levels of gene flow estimated to exceed $N_{\mathrm{e}} \mathrm{m}=5$ (Shulman 1998).

Recent colonisation of new reefs from a single source area could also have resulted in the high genetic similarity of sub-populations; however, the high observed heterozygosity value of the Caribbean stoplight parrotfish population probably indicates a relatively long history undisturbed by significant population bottlenecks that are usually associated with colonisation events.

The Sparisoma viride data yielded several significant $F_{\mathrm{ST}}$ values, which indicates that gene flow in $S$. viride, although high, is not without restriction. Between Curaçao and the other islands, multi-locus $F_{\mathrm{ST}}$ values were statistically significant. Significant single locus $F_{\mathrm{ST}}$ values were found among some of the other sample sites. 


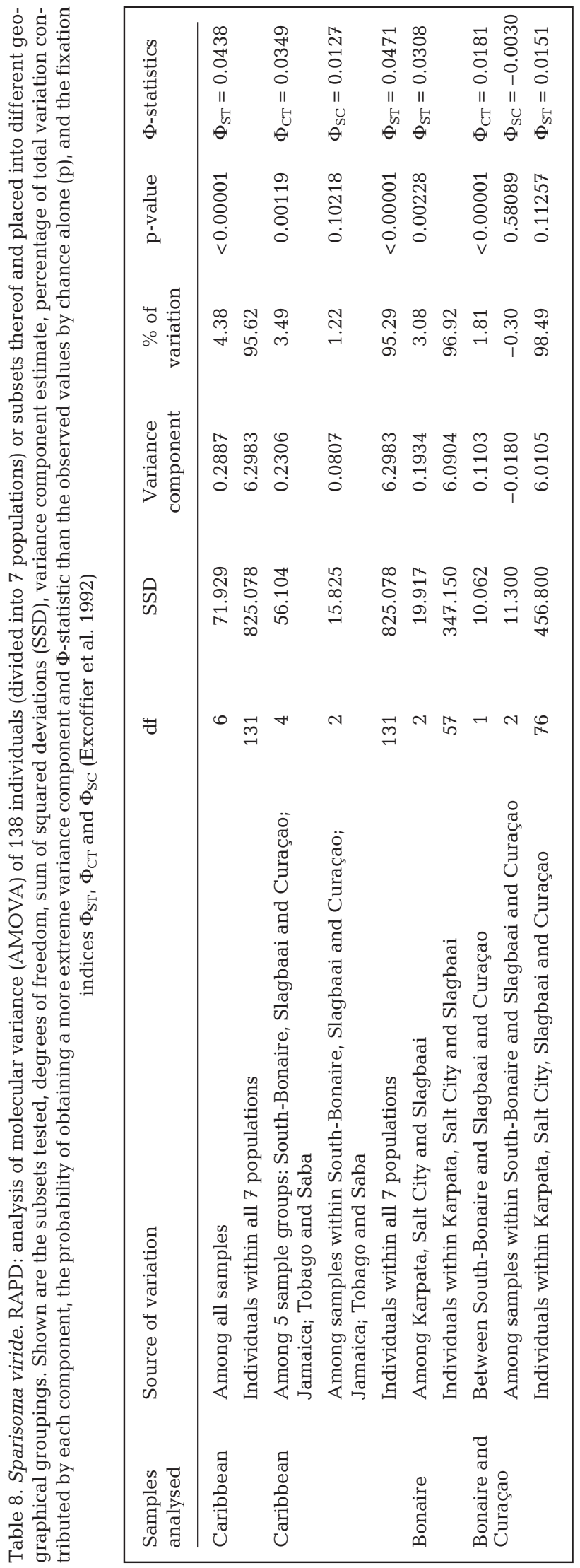

The use of RAPD analysis in combination with AMOVA has proven useful in detecting population structure of natural populations (e.g. see Marmuris et al. 1998b, Lougheed et al. 2000, Hellberg et al. 2002) The $F_{\mathrm{ST}}$ values found by the RAPD analysis are generally of the same order as those found for allozymes; the values are rather low but some differ significantly from zero even after adjusting probabilities by a sequential Bonferroni correction for simultaneous tests. In contrast to the allozyme analysis, RAPDs detected significant $F_{\mathrm{ST}}$ values between the southern and northern area of Bonaire and among 5 sub-populations when Karpata was pooled with Salt City, and the northernmost Bonaire sample (Slagbaai) with Curaçao. This could imply that gene flow is slightly restricted, even along the coast of a single island; however, the absence of allozyme divergence among any of the 3 locations at Bonaire contradicts such a conclusion.

Both methods show the same general picture, relatively high genetic variability and a rather low level of genetic population substructuring, but some differences in details. Most notably, the allozyme electrophoresis slightly discriminates between Curaçao and all the other islands (which pool together), while the RAPD analysis shows low levels of differentiation, more evenly distributed over the entire range of the studied islands. It is not uncommon to find some discordance between the results of different methods in population genetic studies of marine organisms (Hellberg et al. 2002). Marmuris et al. (1998a,b) found different patterns of genetic heterogeneity with their allozyme and RAPD studies of the Mediterranean red mullet Mullus barbatus. In a study of Mediterranean dusky grouper Epinephelus marginatus, the value of $F_{\mathrm{ST}}$ obtained by allozyme analysis was 10 times higher than that found using microsatellites (de Innocentiis et al. 2001). Lemaire et al. (2000) found far higher $F_{\text {ST }}$ values with allozymes than with microsatellites for 8 samples of Mediterranean sea bass Dicentrarchus labrax and they interpret this difference as evidence of non-neutrality of part of the analysed allozymes. Without further study, we can only speculate on the cause of the slight discrepancy between the results of both methods in our study. An explanation may be found in the different sample sizes used in this study; however, both methods studied the same individuals (i.e. the smaller sample was always drawn from the larger sample). It seems unlikely that this random re-sampling could result in such a specific distinction of 1 sample (Curaçao) at several enzyme loci. Allozyme electrophoresis detects DNA differences in transcribed regions of the genome, which cause differences in the net electric charge of the enzymatic products of these regions. Evidence exists that enzyme polymorphisms in fishes can sometimes be maintained by locus-specific natural se- 
Table 9. Sparisoma viride. RAPD analysis. Above the diagonal: pairwise $\Phi_{\mathrm{ST}}$ among samples and pooled samples; ${ }^{*}$ : significant at Bonferroni corrected $\mathrm{p} \leq 0.05$ (5000 permutations). Below the diagonal: the number of migrants per generation, $N_{\mathrm{e}} \mathrm{m}=\left(1-\Phi_{\mathrm{ST}}\right) / 4 \Phi_{\mathrm{ST}}$. (Bonaire: Karpata, Salt City and Slagbaai; South-Bonaire: Karpata and Salt City)

\begin{tabular}{|c|c|c|c|c|c|c|c|c|c|c|}
\hline & Karpata & Salt City & $\begin{array}{l}\text { South- } \\
\text { Bonaire }\end{array}$ & Slagbaai & Bonaire & Curaçao & $\begin{array}{c}\text { Slagbaai and } \\
\text { Curaçao }\end{array}$ & Jamaica & Tobago & Saba \\
\hline Karpata & - & 0.0012 & - & 0.0555 & - & 0.0319 & $0.0382^{*}$ & $0.0507^{*}$ & 0.0188 & $0.0762^{*}$ \\
\hline Salt City & 210 & - & - & 0.0404 & - & 0.0207 & 0.0229 & 0.0337 & 0.0319 & $0.0507^{*}$ \\
\hline South-Bonaire & - & - & - & $0.0497^{*}$ & - & $0.0270^{*}$ & $0.0319^{*}$ & $0.0412^{*}$ & $0.0251^{*}$ & $0.0637^{*}$ \\
\hline Slagbaai & 4 & 6 & 5 & - & - & 0.0208 & - & $0.0694^{*}$ & $0.0452^{*}$ & $0.0959^{*}$ \\
\hline Bonaire & - & - & - & - & - & 0.0131 & - & $0.0377^{*}$ & 0.0198 & $0.0625^{*}$ \\
\hline Curaçao & 8 & 12 & 9 & 12 & 19 & - & - & $0.0522^{*}$ & 0.0253 & 0.0121 \\
\hline Slagbaai and Curaçao & 7 & 11 & 8 & - & - & - & - & $0.0529^{*}$ & $0.0289^{*}$ & $0.0494^{*}$ \\
\hline Jamaica & 5 & 7 & 6 & 3 & 6 & 5 & 4 & - & $0.0357^{*}$ & $0.0864^{*}$ \\
\hline Tobago & 13 & 8 & 10 & 5 & 12 & 10 & 8 & 7 & - & $0.0655^{*}$ \\
\hline Saba & 3 & 5 & 4 & 2 & 4 & 20 & 5 & 3 & 4 & - \\
\hline
\end{tabular}

lection (Utter 1991). RAPDs on the other hand randomly sample the entire genome including the noncoding regions (Williams et al. 1990), which often make up the largest part of the DNA. It is far less likely that DNA regions sampled by RAPDs encode for phenotypic characters that are subject to natural selection than are DNA regions sampled by allozyme analysis. Thus, the population genetic structure that is resolved by RAPDs may reflect patterns caused by migration and genetic drift, while the structure resolved by allozyme electrophoresis may also reflect the effects of selection. As different environmental conditions may exist at all scales within a tropical ocean, selection pressures are probably not geographically uniform (Shulman 1998). However, it seems odd that the population at Curaçao should encounter such specific selection that it slightly differentiated from all others, even from nearby and environmentally very similar Bonaire, whereas no difference should exist among Bonaire and the other geographically distant and environmentally different islands.

Neither method found a relationship between values of pairwise $F_{\mathrm{ST}}$ and geographic distance. Ocean currents probably strongly influence dispersal of Sparisoma viride larvae and may promote exchange of alleles among populations that are situated along the current while hindering it across the current. This seems to be reflected by the RAPD analysis, which shows that the effective number of migrants is larger along the prevailing Caribbean current than across it.

Our results indicate that the local Sparisoma viride sub-populations are relatively open and highly connected. The effective number of migrants among each of the island pairs exceeds 1 per generation. With such migration rates, it is unlikely that the differences in reproductive strategies that were found at different locations could have evolved as adaptations to different local conditions. Although the heritability of alter- native reproductive strategies is not determined, it seems far more plausible that $S$. viride evolved a high intrinsic flexibility allowing individuals to adjust to the conditions encountered in the surroundings into which they happened to recruit.

Acknowledgements. We thank the authorities of Bonaire and the Bonaire Marine Park, especially K. de Meyer and R. Hensen, for permitting sample collection within the Park, and G. Joosten and 2 friends for their help in the field. We thank the director, staff and guests of CARMABI institute at Curaçao for their help and support. At Jamaica, we thank the management, staff and guests of the Discovery Bay Marine Lab, P. Jale and P. Janca, and especially Z. Sary and the fisherman Marvin for their invaluable assistance. We thank the Tobago fisheries department for permitting sample collection. At Saba, we thank the authorities of Saba and the Saba Marine Park for permitting sample collection and P. ten Holt, 'the Haitian' and many other fishermen of Saba for their invaluable help. We thank J. J. de Wiljes, J. L. Olsen, W. T. Stam, M. J. H. van Oppen and S. A. Boele-Bos for their support, help and advice in the lab, and with data analysis. O. E. Diekmann deserves special thanks for cheerfully travelling and diving along, despite injuries sustained in a car accident at Bonaire. This project was supported by grant W88-168 of the Netherlands Foundation for Advancement of Tropical Research (WOTRO). G.J.G. wishes to thank A. Dodo for her persistent support.

\section{LITERATURE CITED}

Aggarwal RK, Lang JW, Singh L (1992) Isolation of highmolecular-weight DNA from small samples of blood having nucleated erythrocytes, collected, transported, and stored at room temperature. GATA 9:54-57

Allendorf FW, Phelps SR (1981) Use of allelic frequencies to describe population structure. Can J Fish Aquat Sci 38: 1507-1514

Barlow GW (1981) Patterns of parental investment, dispersal and size among coral-reef fishes. Environ Biol Fish 6: 65-85

Belkhir K, Borsa P, Chikhi L, Goudet J, Bonhomme F (1997) GENETIX 4.01, Windows ${ }^{\mathrm{TM}}$ Software for Population Genetix. University of Montpellier II, Laboratoire Génome et Populations, Montpellier 
Bernardi G, Robertson DR, Clifton KE, Azzurro E (2000) Molecular systematics, zoogeography, and evolutionary ecology of the Atlantic parrotfish genus Sparisoma. Molec Phyl Evol 15:292-300

Böhlke JE, Chaplin CCG (1993) Fishes of the Bahamas and adjacent tropical waters, 2nd edn. University of Texas Press, Austin

Boisselier-Dubayle MC, Gofas S (1999) Genetic relationships between marine and marginal-marine populations of Cerithium species from the Mediterranean sea. Mar Biol 135:671-682

Bruggemann JH, van Kessel AM, van Rooij JM, Breeman AM (1996) Bioerosion and sediment ingestion by the Caribbean parrotfish Scarus vetula and Sparisoma virideimplications of fish size, feeding mode and habitat use. Mar Ecol Prog Ser 134:59-71

Cardwell JR, Liley NR (1991) Hormonal control of sex and color change in the Stoplight parrotfish, Sparisoma viride. Gen Comp Endocr 81:7-20

de Innocentiis S, Sola L, Cataudella S, Bentzen P (2001) Allozyme and microsatellite loci provide discordant estimates of population differentiation in the endangered dusky grouper (Epinephelus marginatus) within the Mediterranean Sea. Mol Ecol 10:2163-2175

de Moura RL, de Figueiredo JL, Sazima I (2001) A new parrotfish (Scaridae) from Brazil, and revalidation of Sparisoma amplum (Ranzani, 1842), Sparisoma frondosum (Agassiz, 1831), Sparisoma axillare (Steindacher, 1878) and Scarus trispinosus Valenciennes, 1840. Bull Mar Sci 68:505-524

Doherty PJ, Planes S, Mather P (1995) Gene flow and larval duration in 7 species of fish from the Great Barrier Reef. Ecology 76:2373-2391

Engelen AH, Olsen JL, Breeman AM, Stam WT (2001) Genetic differentiation in Sargassum polyceratium (Fucales: Phaeophyceae) around the island of Curaçao (Netherlands Antilles). Mar Biol 139:267-277

Excoffier L, Smouse PE, Quattro JM (1992) Analysis of molecular variance inferred from metric distances among DNA haplotypes: application to human mitochondrial DNA restriction data. Genetics 131:479-491

Geertjes GJ, Kamping A, van Delden W, Videler JJ (2001) Genetic relationships among one non-endemic and two endemic Mediterranean triplefin blennies (Pisces, Blennioidei). PSZN I: Mar Ecol 22:255-265

Goudet J (1994) FSTAT: a program for IBM PC compatibles to calculate Weir and Cockerham's (1984) estimators of F-statistics. Institut de Zoologie et d'Ecologie Animale, Batiment de Biologie, Universite de Lousanne

Grimm V, Reise K, Strasser M (2003) Marine metapopulations: a useful concept? Helgol Mar Res 56:222-228

Gyllensten U (1985) The genetic structure of fish: differences in the intraspecific distribution of biochemical genetic variation between marine, anadromous and freshwater species. J Fish Biol 26:691-699

Harrison S (1991) Local extinction in a metapopulation context: an empirical evaluation. Biol J Linn Soc: 42:73-88

Hellberg ME, Burton RS, Neigel JE, Palumbi SR (2002) Genetic assessment of connectivity among marine populations. Bull Mar Sci 70(Suppl):273-290

Hofman A (1988) Starch gel electrophoresis: a tool for studying the phylogenetic systematics and population genetics of mosses. In: Glime JM (ed) Methods in bryology. Hattori Botanical Laboratory, Nichinan, p 353-358

Huang BX, Peakall R, Hanna PJ (2000) Analysis of genetic structure of blacklip abalone (Haliotis rubra) populations using RAPD, minisatallite and microsatellite markers. Mar Biol 136:207-216
Johannes RE (1978) Reproductive strategies of coastal marine fishes in the tropics. Environ Biol Fish 3:65-84

Koltes KH (1993) Aspects of the reproductive biology and social structure of the stoplight parrotfish Sparisoma viride, at Grand Turk, Turks and Caicos Islands, B.W.I. Bull Mar Sci 52:792-805

Lacson JM (1992) Minimal genetic variation among samples of six species of coral reef fishes collected at La Parguera, Puerto Rico, and Discovery Bay, Jamaica. Mar Biol 112: $327-331$

Lemaire C, Allegrucci G, Naciri M, Bahri-Sfar L, Kara H, Bonhomme F (2000) Do discrepancies between microsatellite and allozyme variation reveal differential selection between sea and lagoon in the sea bass (Dicentrarchus labrax)? Mol Ecol 9:457-467

Lougheed SC, Gibbs HL, Prior KA, Weatherhead PJ (2000) A comparison of RAPD versus microsatellite DNA markers in population studies of the massasauga rattlesnake. J Heredity 91:458-463

Luttikhuizen PC, Drent J, van Delden W, Piersma T (2003) Spatially structured genetic variation in a broadcast spawning bivalve: quantitative vs. molecular traits. J Evol Biol 16:260-272

Mamuris Z, Apostolidis AP, Triantaphyllidis C (1998a) Genetic protein variation in red mullet (Mullus barbatus) and striped mullet ( $M$. surmuletus) populations from the Mediterranean Sea. Mar Biol 130:353-360

Mamuris Z, Apostolidis AP, Theodorou AJ, Triantaphyllidis C (1998b) Application of random amplified polymorphic DNA (RAPD) markers to evaluate intraspecific genetic variation in red mullet (Mullus barbatus). Mar Biol 132: 171-178

Mantel N (1967) The detection of disease clustering and generalized regression approach. Cancer Res 27:209-220

Munro JL, Gaut VC, Thompson R, Reeson PH (1973) The spawning seasons of Caribbean reef fishes. J Fish Biol 5: 69-84

Murphy RW, Sites JW Jr, Buth DG, Haufler CH (1996) Proteins: isozyme electrophoresis. In: Hillis DM, Moritz C, Mable BK (eds) Molecular systematics, 2nd edn. Sinauer Associates, Sunderland, MA, p 51-120

Nei M (1978) Estimation of average heterozygosity and genetic distance from a small number of individuals. Genetics 89:583-590

Planes S, Bonhomme F, Galzin R (1993) Genetic structure of Dascyllus aruanus populations in French Polynesia. Mar Biol 117:665-674

Planes S, Galzin R, Bonhomme F (1996) A genetic metapopulation model for reef fishes in oceanic islands: the case of the convict surgeonfish, Acanthurus triostegus. J Evol Biol 9:103-117

Planes S, Parroni M, Chauvet C (1998) Evidence of limited gene flow in three species of coral reef fishes in the lagoon of New Caledonia. Mar Biol 130:361-368

Rasmuson M (1981) Some aspects of available resources of genetic variation. In: Ryman N (ed) Fish gene pools. Ecol Bull (Stockholm) 34:53-59

Reinboth R (1968) Protogynie bei Papageifischen (Scaridae) Z Naturforsch 23:852-855

Rice RR (1989) Analyzing tables of statistical tests. Evolution 43:223-225

Robertson DR, Warner RR (1978) Sexual patterns in the Labroid fishes of the western Caribbean, II: the parrotfishes (Scaridae). Smithson Contr Zool 255:1-26

Sale PF (1980) The ecology of fishes on coral reefs. Oceanogr Mar Biol 18:367-421

Sambrook J, Fritch EF, Maniatis T (1989) Molecular cloning: a 
laboratory manual, 2nd edn. Cold Spring Harbor Laboratory Press, New York

Schneider S, Kueffer JM, Roessli D, Excoffier L (1997) ARLEQUIN 1.1: a software for population genetic data analysis. Genetics and Biometry Laboratory, University of Geneva, Geneva

Shaklee JB (1984) Genetic variation and population structure in the Damselfish, Stegastes fasciolatus, throughout the Hawaiian Archipelago. Copeia 1984:629-640

Shaklee JB, Allendorf FW, Morizot DC, Whitt GS (1990) Gene nomenclature for protein-coding loci in fishes. Trans Am Fish Soc 119:2-15

Shulman MJ (1998) What can population genetics tell us about dispersal and biogeographic history of coral-reef fishes? Aust J Ecol 23:216-225

Slatkin M (1987) Gene flow and the geographic structure of natural populations. Science 236:787-792

Smith PJ, Fujio Y (1982) Genetic variation in marine teleosts: high variability in habitat specialists and low variability in habitat generalists. Mar Biol 69:7-20

Star B, Apte S, Gardner JPA (2003) Genetic structuring among populations of the greenshell mussel Perna canaliculus revealed by analysis of randomly amplified polymorphic DNA. Mar Ecol Prog Ser 249:171-182

Stobutzki IC (2001) Marine reserves and the complexity of larval dispersal. Rev Fish Biol Fish 10:515-518

Utter FM (1991) Biochemical genetics and fishery management: an historical perspective. J Fish Biol 39(Suppl A):1-20

van Dijk H, van Delden W (1981) Genetic variability in Plantago species in relation to their ecology. I. Genetic analysis of the allozyme variation in $P$. major subspecies. Theor Appl Genet 60:285-290

Editorial responsibility: Otto Kinne (Editor),

Oldendorf/Luhe, Germany van Rooij JM, Kroon FJ, Videler JJ (1996) The social and mating system of the herbivorous reef fish Sparisoma viride: one-male versus multi-male groups. Environ Biol Fish 47: 353-378

van Rooij JM, Videler JJ, Bruggemann JH (1998) High biomass and production but low energy transfer efficiency of Caribbean parrotfish: implications for trophic models of coral reefs. J Fish Biol 53 (Suppl A):154-178

van Treuren R, Bijlsma K, van Delden W, Ouborg NJ (1991) Genetic differentiation in Salvia pratensis and Scabiosa columbaria in relation to population size. Heredity 66: 181-189

Ward RD, Woodwark M, Skibinski DOF (1994) A comparison of genetic diversity levels in marine, freshwater, and anadromous fishes. J Fish Biol 44:213-232

Warner RR, Cowen RK (2002) Local retention of production in marine populations: evidence, mechanisms, and consequences. Bull Mar Sci 70(Suppl):245-249

Weir BS, Cockerham CC (1984) Estimating F-statistics for the analysis of population structure. Evolution 38:1358-1370

White PS, Densmore LD III (1992) Mitochondrial DNA isolation. In: Hoelzel AR (ed) Molecular genetic analysis of populations. IRL Press, Oxford, p 31-58

Williams JGK, Kubelik AR, Livak KJ, Rafalski JA, Tingey SV (1990) DNA polymophisms amplified by arbitrary primers are useful as genetic markers. Nucleic Acids Res 18: 6531-6535

Wright JT, Zuccarello GC, Steinberg PD (2000) Genetic structure of the subtidal red alga Delisea pulchra. Mar Biol 136: $439-448$

Wright S (1951) The genetical structure of populations. Ann Eugen 15:323-354

Submitted: September 26, 2003; Accepted: June 15, 2004

Proofs received from author(s): September 17, 2004 